\title{
Study of role of Panchatikta Basti in Abhishyanda Pradhana Prameha
}

\author{
Dr Mangesh Ganpat Dimble ${ }^{1}$, Dr Yashashree Joshi ${ }^{2}$, Dr Vasudha Asutkar ${ }^{3}$ \\ ${ }^{1}$ lecturer at Samhita and Ayurved Siddhant dept. SSAMC Haveri, RGUHS, Karnataka, India. \\ ${ }^{2}$ Prof and HOD at Samhita and Basic Principles dept. BVDUCOA Pune, Maharashtra, India. \\ ${ }^{3}$ lecturer at Samhita and Basic Principles dept. BVDUCOA Pune, Maharashtra, India.
}

\begin{abstract}
:
Aims: To study effect of Pancatikta-Basti in Abhishyanda-Pradhan-Prameha.

Settings and Design: Panchatikta-Niruha-Basti(medicated enema) has been administered in a dose of $430 \mathrm{ml}$ for 4 consecutive days and on fifth day Sarshapa-Taila(Mustard-oil) 60ml Anuvasan given which is least amount of Sneha(oil). $(4+1=1$ cycle $x 3$ cycle $)$.

Methods and Material: 30 patients were selected for the study. Pachana medicine i.e. Hingvashtak-Churna is given $1 \mathrm{gm}$ with lukewarm water, just before 2meals/day for 5days. Purvakarma:-Snehana-Bahya-Sarvang with Tila-taila and Svedana(sudation): Bashpa Peti (Mild). Panchatikta-Niruha-Basti has been administered accordingly.

Statistical analysis used: Data displayed as Mean $\pm S D$ in case of normally distributed data and Median (Range) in case of data not distributed normally, for quantitative data Paired t test and for qualitative data Mann Whitney test has applied.

Results: As per statistical analysis - Abhishyanda-Pradhan signs have shown significant results $i$. $e$. Prabhutamutrata (excess-urination), Avilamutrata (turbid-urination), Asyamadhuryata (sweet taste in the mouth), Alasya (laziness), Tandra (drowsiness), Nidra (excess sleep), Svedoangandha (foul smell of sweat), Shitapriyatva (desire to cold), Gurugatrata (heaviness in the body), Jihvaupadeha (white coated tongue).

Hastapadataladaha (burning sensation of both palms and sole), Shithilangata (lack of compactness of body tissue), Amlika (hyperacidity), Shula (pain) Badhapurishtva (constipation), Pratishyaya (coryza).

Daurbalya (generalised weakness), Kaphapraseka (excessive moisturization of oral cavity) has shown satisfactory results. Significant results - BSL-F and PP, URINE-SUGAR. Satisfactory results have been seen in Weight and waist circumference.

Conclusions: Panchatikta Basti is significantly effective in Abhishyanda Pradhana Prameha. In this clinical study not a single patient out of 30 patients was complained about any type of Vataprakopa. This Basti is significantly effective in elevated sugar level in blood and urine, excess urination and weigh-gain.
\end{abstract}

Keywords: Abhishyanda, Basti, Prameha, Panchatikta-Basti.

\section{Introduction:}

Prameha may be equated with the DM. Charaka explains it as a life-style disorder, due to over indulgence in heavy and richly nutritious food, day-time sleep, lack of exercises, other sedentary habits and not doing seasonal purifications. ${ }^{[1]}$ All these etiological factors are responsible for formation of Vitiated Kleda (deliquesce) i.e Abhishyanda. The term Abhishyanda is found in Ayurvedic texts in different contexts. It is traced as a cause of diseases like --Hikka, Shvasa, Visarpa, Kushtha, Prameha, Alasaka etc. The practical utility of Abhishyanda (excessive dampness) is important in treating patients. While referring to the meaning of Abhishyanda, a very meaningful explanation is found in Chakrapani commentary Abhishyanda is vitiated Drava dominant Kapha Dosha. ${ }^{[2]}$ With these thoughts, the Scholar has studied Prameha Chikitsa and found Panchatikta Basti especially prescribed for Meha-Abhishyanda. ${ }^{[3]}$ According to Ashatangasamgraha, root cause of Prameha is Abhishyanda ${ }^{[4]}$ This gives a clear idea about the root cause of Prameha i.e. Abhishyanda. The physician must take due cognition of Abhishyanda status of various body factors while treating various diseases and especially treating Prameha, for better success in treatment.

Aim and objectives:

To study effect of Pancatikta Basti in Abhishyanda Pradhan Prameha.

\section{Subjects and Methods:}

A total of 30 patients of Prameha (DM type 2) were registered on the basis of symptomatology and relevant blood and urine test, irrespective of their sex, religion, etc. Written consent was taken from each patient 
after giving him/her detailed information about the Basti treatment. Ethical clearance was also obtained from the Institutional Ethics Committee.

Drug, dose and duration

\section{Methodology:-}

1) Previous medications were stopped.

2) Pachana medicine i.e. Hingvashtak-Churna is given $1 \mathrm{gm}$ with lukewarm water, just before 2 meals/day for 5days.

3) Purvakarma:- Snehana- Sarvang Bahya Snehan with Tila taila.

Svedana: Bashpa peti Sweda (Mild sudation).

SOP of Basti - A Niruha Basti (medicated enema for evacuation of abnormal Dosha) has been given in a condition of empty stomach and Anuvasana (a type of medicated enema of medicated oil) has given immediately after food. Basti Dravya has been given by anal route by simple rubber catheter in left lateral position having right leg flexed towards abdomen and left leg extended.

Anuvasana Basti is contraindicated in Prameha Vyadhi. ${ }^{[5]}$ Whereas Asthapana (Niruha) Basti are specially advised for Prameha as it is Snigdha Kleda dominance disease. ${ }^{[6]}$

Dalhana mentioned that dose of Niruha Basti should be $1 / 3^{\text {rd }}$ or $1 / 2$ less than that of routine dose of Niruha in Snigdha Rugna. ${ }^{[7]}$

Dose of Pancatikta Basti is $430 \mathrm{ml} \&$ it correlates with above calculation.

Chakrapani stated that for aggravated Kapha - Pitta, Anuvasan Basti should be given on $5^{\text {th }}$ day after Niruha Basti. ${ }^{[8]}$ The dose of Sarshapa Anuvasana is $60 \mathrm{ml}$ which is least amount of Sneha Basti.

\section{Design Of Basti Treatment}

Anuvasan is contraindicated and Asthapana is specially advised in Prameha. ${ }^{[9]}$

Dose of Basti - - In Snigdha Rugna, Niruha should be given 1/3rd or $1 / 2$ less than that of routine dose of Niruha. ${ }^{[10]}$ So dose of Pancatikta Basti is $430 \mathrm{ml}$ which correlates above calculation.

[Table no 1 ]

\begin{tabular}{|l|l|l|l|}
\hline Name of drug & Part to be used & Form of medicine & Quantity \\
\hline $\begin{array}{l}\text { Patola } \\
\text { Tricosanthus } \\
\text { Cucumerina }\end{array}$ & Leaf, stem & decoction & \\
\hline $\begin{array}{l}\text { Rāsna } \\
\text { Alpinia galanga }\end{array}$ & Rhizome & decoction & \\
\hline $\begin{array}{l}\text { Bhuniṃba } \\
\text { Andrographis panniculata }\end{array}$ & Whole plant & decoction & $320 \mathrm{ml}$ \\
\hline $\begin{array}{l}\text { Saptaparna } \\
\text { Alstonia scholaris }\end{array}$ & Stem bark & decoction & \\
\hline $\begin{array}{l}\text { Niṃba } \\
\text { Azadirachta indica }\end{array}$ & Stem bark & decoction & \\
\hline $\begin{array}{l}\text { Sarshap } \\
\text { Brassica campetris }\end{array}$ & Seed & Paste & $30 \mathrm{gms}$ \\
\hline Goghruta & & & $80 \mathrm{ml}$ \\
\end{tabular}

Contents of Panchatikta Basti (Table No 2)

\begin{tabular}{|l|l|l|l|l|l|}
\hline Name of drug & Guṇa & Rasa & Veerya & Vipak & Doshaghnata \\
\hline $\begin{array}{l}\text { Patol } \\
\text { Tricosanthus }\end{array}$ & $\begin{array}{l}\text { Laghu, } \\
\text { Snigdha }\end{array}$ & Tikta & Ushṇa & Madhura & Tridoshaghna \\
\hline $\begin{array}{l}\text { Rasna } \\
\text { Alpinia galanga }\end{array}$ & Gurū & Tikta & Ushṇa & Katu & KaphaVātahar \\
\hline $\begin{array}{l}\text { Bhunimba } \\
\text { Andrographis } \\
\text { panniculata }\end{array}$ & $\begin{array}{l}\text { Laghu, } \\
\text { Rūksha }\end{array}$ & Tikta & Ushṇa & Katu & KaphaPittaghna \\
\hline $\begin{array}{l}\text { Saptaparna } \\
\text { Alstonia scholaris }\end{array}$ & $\begin{array}{l}\text { Laghu, } \\
\text { Snigdha }\end{array}$ & $\begin{array}{l}\text { Tikta } \\
\text { kashaya }\end{array}$ & Ushṇa & Katu & Kapha Vātaghna \\
\hline $\begin{array}{l}\text { Nimba } \\
\text { Azadirachta indica }\end{array}$ & Laghu & $\begin{array}{l}\text { Tikta } \\
\text { Kashaya }\end{array}$ & Șita & Katu & Pitta Kaphaghna \\
\hline $\begin{array}{l}\text { Sarshap } \\
\text { Brassica campetris }\end{array}$ & $\begin{array}{l}\text { Snigdha, } \\
\text { Tikshna }\end{array}$ & $\begin{array}{l}\text { Katu } \\
\text { Tikta }\end{array}$ & Ushṇa & Katu & Kapha Vātaghna \\
\hline Goghruta & & Madhura & Șìta & Madhura & Pitta Vātaghna \\
\hline
\end{tabular}


Logic Behind The Sequence Of Basti $(4+1 \times 3$ CYCLE $)-{ }^{[11]}$

Chakrapani stated that in aggravated Kapha-Pitta, Anuvasana Basti should be given on $5^{\text {th }}$ day, it's clear from above verse that 4 Niruha Basti have to be administered consecutively and to avoid Vataprakopa, on $5^{\text {th }}$ day Sarshapa Sneha in $60 \mathrm{ml}$ which is a least amount and is advised in Prameha. ${ }^{[12]}$

\section{Criteria For Primary End Point}

Minimum one cycle $4+1 \& \max 3$ cycles (4+1) has been administered until Lakshanatmaka Upashaya (symptomatic relief) is achieved. Basti administration has been stopped with Sarshapa Sneha Basti.

\section{[Table No 3]}

\begin{tabular}{|l|l|l|l|}
\hline Cycle & 1 & 2 & 3 \\
\hline Basti & N N N A & N N N A & N N N N A \\
\hline Days & 12345 & 678910 & 1112131415 \\
\hline
\end{tabular}

( $\mathrm{N}=$ Niruha, $\mathrm{A}=$ Anuvasan Basti)

With these guidelines, following Basti treatment is planned.

This $(4+1 \times 3)$ cycle has been given according to signs and symptoms of patient. Minimum one cycle of Basti $(4+1)$ and maximum 3 cycles of

(4+1)has been administered.

The drugs for Basti were self collected, and authenticated.

\section{Inclusion criteria}

Patients having symptoms of Prameha according to Brihattrayi irrespective of sex, BSL.

Patients having DM-TYPE 2 with symptoms of classical Prameha Vyadhi \& essentially urine sugar traced.

\section{Exclusion criteria}

Age - below 20 and above 60 years.

Patients with Vata dominance (Ati Apatarpan).

\section{Assessment criteria}

A change in severity index of sign and symptoms has been prime criteria of assessment.

Haematological and urine investigation related with DM has been advised before and after treatment.

\section{Criteria for assessment}

Improvement observed in patients was assessed mainly on the basis of change in severity index of sign and symptoms of Prameha.

Urine for Sugar, blood sugar level (BSL)

Subjective parameters like changes in weight, waist circumference.

\section{Statistical Analysis}

The data obtained in the study was subjected to statistical tests.

The effect of the Basti on anthropometric measurements and other investigations are shown in the following table:

[Table No 4]

\begin{tabular}{|c|c|c|}
\hline Parameter & Pre-treatment & After completion of treatment \\
\hline Weight $(\mathrm{Kg})$ & $71.86 \pm 7.39$ & $69.58 \pm 6.61 * * *$ \\
\hline Waist circumference $(\mathrm{cm})$ & $39.68 \pm 1.77$ & $37.96 \pm 1.49 * * *$ \\
\hline FBS (mg/dl) & $191.08 \pm 63.35$ & $105.36 \pm 18.63$ *** \\
\hline PLBS & $260.63 \pm 55.63$ & $157.79 \pm 27.72 * * *$ \\
\hline Urine sugar & $3(2-5)$ & $0(0-1)^{\varrho @ @ ~}$ \\
\hline
\end{tabular}

Data displayed as Mean \pm SD in case of normally distributed data and Median (Range) in case of data not distributed normally, ***p $<0.001$ as compared to pre-treatment using Paired t test, ${ }^{@ @ ~} \mathrm{p}<0.001$ as compared to pre-treatment using Mann Whitney test.

The effect of the Basti on Abhishyand predominance symptoms are shown below:

[Table No 5]

\begin{tabular}{|l|l|l|}
\hline Symptoms & Pre-treatment & After completion of treatment \\
\hline Prabhut Mutrata & $7(5-8)$ & $1(0-5)^{@ @ @ ~}$ \\
\hline Avil Mutrata & $7(0-8)$ & $1(0-4)^{@ @ @ ~}$ \\
\hline Aasya madhurya & $7(0-8)$ & $1(0-3)^{@ @}$ \\
\hline
\end{tabular}


Study of role of Panchatikta Basti in Abhishyanda Pradhana Prameha

\begin{tabular}{|l|l|l|}
\hline Alasya & $7(0-8)$ & $0(0-3) @ @ ~$ \\
\hline Tandra & $7(0-8)$ & $0(0-2)^{@ @}$ \\
\hline Nidra & $0(0-8)$ & $0(0-2)$ \\
\hline Saad & $7(0-8)$ & $0(0-4)$ \\
\hline Kaychidreshu updeha & $0(0-8)$ & $0(0-3)$ \\
\hline Swedonga gandha & $5(0-9)$ & $0(0-3)^{@}$ \\
\hline Guru gatrata & $7(0-9)$ & $1(0-2)^{@ @}$ \\
\hline Jivha updeha & $5(0-8)$ & $1(0-2)^{@ @}$ \\
\hline Shithilangata & $7(0-8)$ & $3(0-4)$ \\
\hline
\end{tabular}

Data displayed as Median (Range), ${ }^{@} \mathrm{p}<0.05$, $@ \mathrm{p}<0.01 @ \mathrm{p}<0.001$ as compared to pre-treatment using Mann Whitney test.

\section{Results:}

After giving consequent 4 Niruha Basti not a single symptom of Vataprokopa has been noted.

Abhishyanda dominance signs have shown significant results i.e

Prabhutamutrata (excess-urination), Avilamutrata (turbid-urination), Asyamadhuryata (sweet taste in the mouth), Alasya (laziness), Tandra (drowsiness), Nidra (excess sleep), Svedoangandha (foul smell of sweat), Shitapriyatva (desire to cold) Gurugatrata (heaviness in the body), Jihvaupadeha (white coated tongue).

Hastapadataladaha (burning sensation of both palms and sole), Shithilangata (lack of compactness of body tissue) Amlika (hyperacidity), Shula(pain) Badhapurishtva (constipation), Pratishyaya (coryza).

Daurbalya (generalised weakness), Kaphapraseka (excessive moisturization of oral cavity) - have shown satisfactory results.

Significant results have been seen in BSL-F, BSL-PP, and urine-sugar.

Satisfactory results have been seen in Weight and waist circumference.

The symptoms such as Arocaka(tastelessness), Kasa(cough) are insignificant statistically but clinically these symptoms are significant.

Niruha Basti has to be administered consequently up to 4 Basti in the Kapha-Pitta dominance condition.

Being Yapya disease, repetition of this Basti has to be carried out periodically as once in year.

\section{Discussion:}

Panchatikta Basti is specially prescribed for MehaAbhishyanda in Caraka Samhita. Kaphaja Prameha, being an Abhishyanda Pradhana Prameha is a perfect indication for administration of this Basti. Furthermore, it is a disease which has a vast Dushya Sangraha involved in its Samprapti(pathogenesis). Considering this, it is decided to access efficiency of Panchatikta Basti as 'Meha-Abhishyanda' or 'Abhishyanda Pradhana Prameha'. All the contents of this Basti are Tikta(bitter), Katu(spicy) and Kashaya(astringent) Rasa dominant in nature, Kapha-Pittaghna. Almost all ingredients of this Basti have Kledahara action which depletes Abhishyanda and leads to cleansing of micro pore as well as macro pores of various channels. Consequently, proper secretions and circulation can take place in the Annavaha-Srotas(elementary canal) as well as in the peripheral organs. Following Abhishyanda dominance symptoms,

Such as -

Prabhutamutrata, Avilmutrata, Asyamadhuryata, Alasya, Tandra, Nidra, Svedoangandha, Shitapriyatva GuruGatrata, Jihva upadeha.

Abhishyanda is adherent and stagnated in various parts of body and is responsible for above symptoms.

These symptoms are relieved after administration of this Basti ( ref table no $4 \& 5$ ), due to the expulsion of vitiated Kleda i.e. Abhishyanda from micro as well as macro channels and Dhatu. This leads to enhance the strength of Dhatus.

As this Basti eradicates the root cause of Prameha i.e. Abhishyanda, results into strengthening the Srotas (channels). This leads to strengthening of body.

The impurities (Mala) are drained out of the body with this Basti. So the progress of Pathogenesis of Prameha is lowered down which results in reducing probability of complications. Consequently Yapana of Prameha is achieved.( Yapan $=$ a treatment modality which keeps Dosha, Dhatu and Mala in equilibrium state)

\section{Conclusion:}

Panchatikta Basti is significantly effective in Abhishyanda Pradhana Prameha. In this clinical study not a single patient out of 30 patients was complained about any type of Vataprakopa. This Basti is significantly effective in sugar, urine and weight.

\section{Acknowledgement:}

We acknowledge Dr Supriya Bhalerao (IRSHA, BVDU, Pune)for her valuable guidance in statistical analysis. 


\section{References:}

[1]. Agnivesha, Charaka, Dridhabala, Charaka Samhita, Chikitsa Sthana, Prameha Chikitsa, 6/4, Brahmanand Tripathi editor. Reprint ed. Chaukhamba Surbharati Prakashan, Varanasi, 2006; 279

[2]. Chakrapanidutta, Commnetator. Charaka Samhita, Sutra Sthana, Sneha Adhyaya, 13/55-56, Reprint ed. Jadavaji Trikamji Acharya, editor. Chaukhamba Prakashan, Varanasi, 2009; 85.

[3]. Ibidem Chakrapanidutta, Commnetator. Charaka Samhita, Siddhi Sthana,Prasrutayogiya Adhyaya, 8/8;713.

[4]. Indu commentator, Ashtangsangraha, Chikitsa Sthana, Prameha Chikitsa 14/2, Dr.jyotimitra Acharya,editor- Dr Shivprasad Sharma. 3rd ed. Chowkhamba Sanskrit series, Varanasi, 2008; 512

[5]. Ibidem, Charaka Samhita, Siddhi Sthana, Panchakarmiya siddhi Adhyaya, 2/17; 1184.

[6]. Dalhana, Commnetator Sushruta, Susruta Saṃhita, Chikitsa Sthana, Netrabastipraman Pravibhaga Chikitsa, 35/22, Vaidya Yadav Ji Trikam Ji and Narayan Ram Acarya Chowkhamba Surbharti Prakashan, Varanasi,Reprint Edition 2012;527.

[7]. Ibidem Dalhana, Commnetator. Susruta Saṃita, Chikitsa Sthana, AnuvasanottarBasti Chikitsa Adhyaya, $37 / 80,536$.

[8]. Ibidem Chakrapanidutta, Commnetator. Charaka Samhita, Siddhi Sthana,Kalpana Siddhi Adhyaya, 1/23-24; 681

[9]. Ibidem, Dalhana, Commnetator Susruta Samhita, Chikitsa Sthana, Netrabastipraman Pravibhaga Chikitsa, 35/22; 527.

[10]. Ibidem,Dalhana,Commnetator. Susruta Saṃhita, Chikitsa Sthana, AnuvasanottarBasti Chikitsa Adhyaya, $37 / 80 ; 536$

[11]. Ibidem, Dalhana, Commnetator. Susruta Saṃhita, Chikitsa Sthana, AnuvasanottarBasti Chikitsa Adhyaya, $37 / 78 ; 536$

[12]. Ibidem, Chakrapanidutta, Commnetator. Charaka Samhita, Siddhi Sthana,Kalpana Siddhi Adhyaya, 1/23-24 ; 681 